\title{
Transfer of Enterobacter agglomerans (Beijerinck 1888) Ewing and Fife 1972 to Pantoea gen. nov. as Pantoea agglomerans comb. nov. and Description of Pantoea dispersa sp. nov.
}

\author{
FRANÇOISE GAVINI, ${ }^{1 *}$ JORIS MERGAERT, ${ }^{2}$ AMOR BEJI, ${ }^{1}$ CHRISTINE MIELCAREK, ${ }^{1}$ \\ DANIEL IZARD,,$^{1,3}$ KAREL KERSTERS, ${ }^{2}$ AND JOZEF DE LEY ${ }^{2}$ \\ Unité 146, Institut National de la Santé et de la Recherche Médicale, Domaine du Centre d'Enseignement et de \\ Recherches Techniques en Industrie Alimentaire, F-5965I Villeneuve d'Ascq Cédex, France ${ }^{1}$, Laboratorium \\ voor Microbiologie en Microbiële Genetica, Rijksuniversiteit, B-9000 Ghent, Belgium ${ }^{2}$; and \\ Service de Bactériologie A, Faculté de Médecine, F-59045 Lille Cédex, France ${ }^{3}$
}

\begin{abstract}
Deoxyribonucleic acid (DNA)-DNA hybridization was performed with 10 strains belonging to the "Erwinia herbicola-Enterobacter agglomerans complex" by using the competition method on nitrocellulose filters. These strains exhibited more than $75 \%$ DNA binding to Erwinia herbicola ATCC $14589^{\mathrm{T}}(\mathrm{T}=$ type strain) and constitute DNA hybridization group 14589 (including strains ATCC 14589 ${ }^{T}$ and CDC 1429-71 from DNA hybridization group III [D. J. Brenner, G. R. Fanning, J. K. Leete Knutson, A. G. Steigerwalt, and M. J. Krichevsky, Int. J. Syst. Bacteriol. 34:45-55, 1984]). The high level of genomic relatedness of these strains was confirmed by the similarities observed in their electrophoretic protein patterns. On the basis of our data, DNA hybridization group 14589 constitutes a discrete species within the family Enterobacteriaceae. Its closest relative is DNA hybridization group 27155 (41 to $53 \%$ DNA relatedness), which was previously defined and includes the type strains, among others, of Enterobacter agglomerans, Erwinia herbicola, and Erwinia milletiae (A. Beji, J. Mergaert, F. Gavini, D. Izard, K. Kersters, H. Leclerc, and J. De Ley, Int. J. Syst. Bacteriol. 38:77-88, 1988). We propose to unite DNA hybridization groups 14589 and 27155 in a single genus, Pantoea gen. nov. Pantoea agglomerans (Beijerinck 1888) comb. nov. is proposed to contain most strains of DNA hybridization group 27155 (including DNA hybridization group XIII of Brenner et al.), and its type strain is strain ATCC 27155 (= NCTC 9381 = LMG 1286). Pantoea dispersa sp. nov. is proposed to contain DNA hybridization group 14589, and its type strain is strain ATCC 14589 (= LMG 2603). Descriptions of the genus and its two species are given.
\end{abstract}

On the basis of a numerical phenotypic analysis of 169 strains belonging to the "Erwinia herbicola-Enterobacter agglomerans complex," Gavini et al. (11) described five major groups that were divided into 15 subgroups. Verdonck et al. (32) classified about 140 strains of Erwinia herbicola, Erwinia milletiae, and Enterobacter agglomerans into 23 different phena. Brenner et al. (3) studied levels of deoxyribonucleic acid (DNA) relatedness among 124 strains and found that 90 of these strains were distributed over 13 DNA hybridization groups. Using a similar hybridization technique, Lind and Ursing (23) showed that 52 of 86 Enterobacter agglomerans clinical isolates were closely related to each other and to the type strain of the species, as well as to the type strains of Erwinia herbicola and Erwinia milletiae. More recently, the study of Beji et al. (1) conducted with strains belonging to phenotypic groups B4 of Gavini et al. (11) and 7B and 8 of Verdonck et al. (32) pointed out the high levels of DNA relatedness ( 72 to $97 \%$ DNA binding) among the type strains of these three species, 21 strains belonging to group B4, and two strains belonging to DNA hybridization group XIII of Brenner et al. (3). A somewhat lower level of DNA binding (62\%) was noticed with strain CDC 3482-71, a member of group $\mathrm{V}$ of Brenner et al. (3). The synonymy of the species names Enterobacter agglomerans, Erwinia herbicola, and Erwinia milletiae, which was suspected based on the high protein electrophoretic and phenotypic similarities among the type strains of these species $(27,32)$ and was demonstrated by DNA hybridization (23), was confirmed by

\footnotetext{
* Corresponding author.
}

Beji et al. (1). An emended description of these species, defined as DNA hybridization group 27155, was given by these authors (1). Previously, groups E2, E3, and E5 of Gavini et al. (11) and DNA hybridization group XI of Brenner et al. (3) were shown to constitute the species Escherichia adecarboxylata (14). In contrast to the findings of Izard et al. (15) and Brenner et al. (3), Tamura et al. (31) found only very low levels of DNA binding (less than 13\%) between strains belonging to Escherichia adecarboxylata and strains of Enterobacter species and renamed the former taxon Leclercia adecarboxylata.

The aim of this study was to analyze another phenotypic group, group B5 of Gavini et al. (11), four strains of which were present in phenotypic group 10 of Verdonck et al. (32). We determined (i) whether the eight strains of group B5 and four additional strains belonging to phenotypic group 10 of Verdonck et al. (32) could be characterized as a single genomic, protein electrophoretic, and phenotypic subset of the Erwinia herbicola-Enterobacter agglomerans complex, (ii) whether this subset could be separated at the species level from DNA hybridization group 27155 as defined by Beji et al. (1), and (iii) the levels of genomic relatedness of these strains to other groups within the Erwinia herbicola-Enterobacter agglomerans complex $(3,11)$, to other species of the genera Erwinia and Enterobacter, and to other species of the family Enterobacteriaceae.

We propose a new genus, Pantoea, which includes the following two species: Pantoea agglomerans comb. nov. for most strains belonging to DNA hybridization group 27155 of Beji et al. (1) (including the type strains, among others, of 
TABLE 1. Strains used and levels of relative binding of their DNAs to $\left[{ }^{3} \mathrm{H}\right] \mathrm{DNA}$ from Pantoea dispersa ATCC $14589^{\mathrm{T}}$

\begin{tabular}{|c|c|c|c|}
\hline Group & Species name as received & Strain $^{\prime \prime}$ & $\begin{array}{l}\text { \% of relative DNA } \\
\text { binding to }\left[{ }^{3} \mathrm{H}\right] \mathrm{DNA} \text { from } \\
\text { strain ATCC } 14589^{\mathrm{rb}} \\
\end{array}$ \\
\hline \multirow{10}{*}{$\begin{array}{l}\text { Strains assigned by us to Pantoea } \\
\text { dispersa (DNA hybridization group } \\
\text { 14589) }\end{array}$} & Erwinia herbicola & $\operatorname{ATCC} 14589^{\mathrm{Tc}}$ & 100 \\
\hline & Enterobacter agglomerans & Lille $214-6$ & 92 \\
\hline & Enterobacter agglomerans & Gilardi 961 & 89 \\
\hline & Erwinia herbicola & Graham G146 & 88 \\
\hline & Enterobacter agglomerans & Gilardi 968 & 87 \\
\hline & Erwinia herbicola & NCPPB $2279(=$ LMG 2601) & 87 \\
\hline & Enterobacter agglomerans & CDC $1429-71^{c}$ & 85 \\
\hline & Enterobacter agglomerans & Goullet 29.2 .80 & 81 \\
\hline & Erwinia herbicola & NCPPB 2285 (= LMG 2602) & 78 \\
\hline & Erwinia herbicola & IPO 445 (= LMG 2604) & 76 \\
\hline \multirow{6}{*}{$\begin{array}{l}\text { Strains assigned by us to Pantoea } \\
\text { agglomerans }\end{array}$} & Erwinia herbicola & ICPB 2953 & 53 \\
\hline & Erwinia herbicola & Graham G150 (= LMG 2581) & 52 \\
\hline & Enterobacter agglomerans & ATCC $12287^{d}$ & 49 \\
\hline & Erwinia milletiae & NCPPB $2519^{\mathrm{T}}\left(=\right.$ LMG $\left.2660^{\mathrm{T}}\right)$ & 46 \\
\hline & Enterobacter agglomerans & $\begin{array}{l}\operatorname{ATCC} 27155^{\mathrm{T}}\left(=\operatorname{NCTC} 9381^{\mathrm{T}}=\right. \\
\quad \operatorname{LMG~1286})\end{array}$ & 44 \\
\hline & Erwinia herbicola & NCPPB $2971^{\mathrm{T}}\left(=\right.$ LMG $\left.2565^{\mathrm{T}}\right)$ & 41 \\
\hline \multirow{3}{*}{$\begin{array}{l}\text { Other strains belonging to phenotypic } \\
\text { group B5 of Gavini et al. or group } 10 \\
\text { of Verdonck et al. }{ }^{e}\end{array}$} & Enterobacter agglomerans & Gilardi 1030 & 44 \\
\hline & Enterobacter agglomerans & Gilardi 953 & 41 \\
\hline & Erwinia herbicola & Angers B.6.2 & 39 \\
\hline \multicolumn{4}{|l|}{$\begin{array}{l}\text { Other phenotypic groups within the } \\
\text { Erwinia herbicola-Enterobacter } \\
\text { agglomerans complex according to } \\
\text { Gavini et al. }\end{array}$} \\
\hline B1 & Erwinia herbicola & Angers $243-3$ & 32 \\
\hline B2 & Erwinia herbicola & Angers A.17.6 & 27 \\
\hline B6 & Enterobacter agglomerans & Gilardi 959 & 30 \\
\hline B7 & Enterobacter agglomerans & Richard 13-78 & 16 \\
\hline B9 & Erwinia herbicola & Angers $217-8$ & 37 \\
\hline E1 & Atypical coliform & Gavini 98 & 32 \\
\hline \multicolumn{4}{|l|}{$\begin{array}{l}\text { Other DNA hybridization groups within } \\
\text { the Erwinia herbicola-Enterobacter } \\
\text { agglomerans complex according to } \\
\text { Brenner et al. }{ }^{g}\end{array}$} \\
\hline II & Enterobacter agglomerans & CDC $3123-70$ & 43 \\
\hline IV & Enterobacter agglomerans & CDC 1741-71 & 45 \\
\hline V & Enterobacter agglomerans & CDC 3482-71 & 43 \\
\hline VI & Enterobacter agglomerans & CDC 6070-69 & 29 \\
\hline VII & Enterobacter agglomerans & CDC 6003-71 & 47 \\
\hline VIII & Enterobacter agglomerans & CDC 5422-69 & 43 \\
\hline IX & Enterobacter agglomerans & CDC 4388-71 & 21 \\
\hline $\mathrm{X}$ & Enterobacter agglomerans & CDC $1600-71$ & 20 \\
\hline XII & Enterobacter agglomerans & CDC 219-71 & 31 \\
\hline \multirow[t]{5}{*}{ Other Erwinia species } & Erwinia stewartii & NCPPB $2295^{\mathrm{T}}$ & 51 \\
\hline & Erwinia uredovora & NCPPB $800^{\mathrm{T}}$ & 47 \\
\hline & Erwinia ananas & NCPPB $1846^{\mathrm{T}}$ & 39 \\
\hline & Erwinia carotovora & $\operatorname{ATCC} 15713^{\mathrm{T}}$ & 28 \\
\hline & Erwinia amylovora & ATCC $15580^{\mathrm{T}}$ & 28 \\
\hline \multirow[t]{10}{*}{ Other Enterobacter species } & $\begin{array}{l}\text { Enterobacter dissolvens } \\
\quad(\text { synonym, Erwinia dissolvens) }\end{array}$ & NCPPB $1850^{\mathrm{T}}$ & 35 \\
\hline & Enterobacter amnigenus & ATCC $33072^{\mathrm{T}}$ & 24 \\
\hline & Enterobacter sakazakii & ATCC $29544^{\mathrm{T}}$ & 23 \\
\hline & $\begin{array}{l}\text { Enterobacter aerogenes } \\
\quad \text { (synonym, Klebsiella mobilis) }\end{array}$ & ATCC $13048^{\mathrm{T}}$ & 22 \\
\hline & Enterobacter asburiae & ATCC $35953^{\mathrm{T}}$ & 21 \\
\hline & Enterobacter cloacae & ATCC $13047^{\mathrm{T}}$ & 20 \\
\hline & & CDC $1347-71$ & 18 \\
\hline & Enterobacter gergoviae & CIP $76.01^{\mathrm{T}}$ & 19 \\
\hline & Enterobacter taylorae & $\operatorname{ATCC} 35313^{\mathrm{T}}$ & 17 \\
\hline & Enterobacter intermedium & CIP $79.27^{\mathrm{T}}$ & 15 \\
\hline
\end{tabular}


TABLE 1-Continued

\begin{tabular}{|c|c|c|c|}
\hline Group & Species name as received & Strain $^{a}$ & $\begin{array}{l}\% \text { of relative DNA } \\
\text { binding to }\left[{ }^{3} \mathrm{H}\right] \mathrm{DNA} \text { from } \\
\text { strain ATCC } 14589^{\mathrm{T} b}\end{array}$ \\
\hline $\begin{array}{l}\text { Other members of the } \\
\text { Enterobacteriaceae }\end{array}$ & $\begin{array}{l}\text { Escherichia blattae } \\
\text { Citrobacter diversus } \\
\text { Escherichia hermannii } \\
\text { Kluyvera cryocrescens } \\
\text { Leclercia adecarboxylata } \\
\text { Klebsiella pneumoniae } \\
\text { Escherichia vulneris } \\
\text { Salmonella typhimurium } \\
\text { Serratia liquefaciens } \\
\text { Cedecea neteri } \\
\text { Levinea amalonatica } \\
\text { Serratia grimesii } \\
\text { Hafnia alvei } \\
\text { Cedecea lapagei } \\
\text { Ewingella americana } \\
\text { Leminorella grimontii } \\
\text { Cedecea davisae } \\
\text { Tatumella ptyseos } \\
\text { Kluyvera ascorbata } \\
\text { Serratia fonticola } \\
\text { Klebsiella planticola } \\
\text { Buttiauxella agrestis } \\
\text { Citrobacter freundii } \\
\text { Klebsiella oxytoca } \\
\text { Serratia odorifera } \\
\text { Escherichia coli } \\
\text { Klebsiella terrigena } \\
\text { Koserella trabulsii } \\
\text { Serratia marcescens } \\
\text { Edwardsiella tarda } \\
\text { Escherichia fergusonii } \\
\text { Yersinia enterocolitica } \\
\text { Proteus vulgaris } \\
\text { Budvicia aquatica } \\
\text { Rahnella aquatilis } \\
\text { Serratia ficaria } \\
\text { Leminorella richardii }\end{array}$ & $\begin{array}{l}\text { ATCC } 29907^{\mathrm{T}} \\
\text { CDC } 3613-63 \\
\text { ATCC } 33650^{\mathrm{T}} \\
\text { ATCC } 33435^{\mathrm{T}} \\
\text { CDC } 5378-71 \\
\text { Leclerc } 35 \\
\text { ATCC } 13882 \\
\text { ATCC } 33821^{\mathrm{T}} \\
\text { ATCC } 23565 \\
\text { ATCC } 27592^{\mathrm{T}} \\
\text { ATCC } 33855^{\mathrm{T}} \\
\text { CDC } 25406 \\
\text { ATCC } 14460^{\mathrm{T}} \\
\text { ATCC } 13337^{\mathrm{T}} \\
\text { CIP } 80.35^{\mathrm{T}} \\
\text { ATCC } 33852^{\mathrm{T}} \\
\text { ATCC } 33999 \\
\text { CIP } 80.344^{\mathrm{T}} \\
\text { ATCC } 33301^{\mathrm{T}} \\
\text { ATCC } 33433^{\mathrm{T}} \\
\text { ATCC } 29844^{\mathrm{T}} \\
\text { ATCC } 33531^{\mathrm{T}} \\
\text { ATCC } 33320^{\mathrm{T}} \\
\text { ATCC } 8090 \\
\text { ATCC } 13182^{\mathrm{T}} \\
\text { CDC } 1979-77^{\mathrm{T}} \\
\text { ATCC } 10536 \\
\text { CIP } 80.07^{\mathrm{T}} \\
\text { CDC } 3349-72^{\mathrm{T}} \\
\text { ATCC } 13880^{\mathrm{T}} \\
\text { ATCC } 15947^{\mathrm{T}} \\
\text { CDC } 0568-73^{\mathrm{T}} \\
\text { CIP } 80.27^{\mathrm{T}} \\
\text { ATCC } 13315 \\
\text { ATCC } 35567^{\mathrm{T}} \\
\text { ATCC } 30701^{\mathrm{T}} \\
\text { ATCC } 33105^{\mathrm{T}} \\
\text { ATCC } 33998^{\mathrm{T}}\end{array}$ & $\begin{array}{l}37 \\
37 \\
36 \\
32 \\
30 \\
26 \\
28 \\
27 \\
26 \\
25 \\
25 \\
24 \\
23 \\
23 \\
23 \\
23 \\
23 \\
22 \\
22 \\
21 \\
20 \\
19 \\
19 \\
18 \\
18 \\
18 \\
17 \\
17 \\
16 \\
16 \\
15 \\
13 \\
11 \\
10 \\
1 \\
9 \\
9 \\
4\end{array}$ \\
\hline
\end{tabular}

${ }^{a}$ Abbreviations and sources: ATCC, American Type Culture Collection, Rockville, Md.; Angers, Laboratoire de Phytophathologie, Angers, France; CDC, Centers for Disease Control, Atlanta, Ga.; CIP, Collection de l'Institut Pasteur, Paris, France; Gavini, F. Gavini, Unite 146, Institut National de la Santé et de la Recherche Médicale, Villeneuve d'Ascq, France (11); Gilardi, G. L. Gilardi, Hospital for Joint Diseases and Medical Center, New York, N.Y. (12); Goullet, P. Goullet. Laboratoire de Microbiologie, Faculté de Médecine Xavier Bichat, Université de Paris, Paris, France; Graham, D. C. Graham, Department of Agriculture and Fisheries for Scotland, Agricultural Scientific Services, Edinburgh, Scotland (13); ICPB, International Collection of Phytopathogenic Bacteria, University of California, Davis; IPO, Instituut voor Plantenziektenkundig Onderzoek, Wageningen, The Netherlands; Leclerc, H. Leclerc, Unite 146, Institut National de la Santé et de la Recherche Médicale, Villeneuve d'Ascq, France (20); Lille, Laboratoire d'Hydrobiologie, Institut Pasteur, Lille, France; LMG, Culture Collection, Laboratorium voor Microbiologie, Ghent, Belgium; NCPPB, National Collection of Plant Pathogenic Bacteria, Harpenden, England; NCTC, National Collection of Type Cultures, London, England; Richard, C. Richard, Service des Entérobactéries, Institut Pasteur, Paris, France (28).

${ }^{b}$ Experiments were performed at the optimal renaturation temperature (see Materials and Methods).

' Strain belonging to DNA hybridization group III of Brenner et al. (3).

${ }^{d}$ Strain belonging to DNA hybridization group XIII of Brenner et al. (3).

$e$ See references 11 and 32 .

$f$ See reference 11 .

${ }^{g}$ See reference 3 .

Enterobacter agglomerans, Erwinia herbicola, and Erwinia milletiae) and Pantoea dispersa sp. nov. for DNA hybridization group 14589 , as defined below.

\section{MATERIALS AND METHODS}

Strains used. The 87 strains used in this study are listed in Table 1.

DNA-DNA hybridization. To prepare DNA, cells were grown in nutrient broth at $30^{\circ} \mathrm{C}$ for $24 \mathrm{~h}$ with shaking. Erwinia herbicola ATCC $14589^{\mathrm{T}}(\mathrm{T}=$ type strain) was selected for the preparation of DNA labeled with $\left[{ }^{3} \mathrm{H}\right]$ thymidine. A modification of the method of Marmur (24) as described by Ferragut and Leclerc (10) was used to prepare both unlabeled and ${ }^{3} \mathrm{H}$-labeled DNAs. Unlabeled high-molecular-weight DNA was fixed and denaturated on nitrocellulose filters by using the technique described by De Ley and Tytgat (7). Fragmentation of DNA was carried out by using a French pressure cell at $20,000 \mathrm{lb} / \mathrm{in}^{2}$. DNA-DNA reassociation was done in $2 \times \mathrm{SSC}(1 \times \mathrm{SSC}$ is $0.15 \mathrm{M} \mathrm{NaCl}$ plus $0.015 \mathrm{M}$ trisodium citrate, $\mathrm{pH} 7.0$ ) containing $30 \%$ dimethyl sulfoxide. The optimal temperature of renaturation in $2 \times \mathrm{SSC}$ containing $30 \%$ dimethyl sulfoxide $\left(T_{O R, D}\right)$ was calculated by using the following equation of De Ley and Tytgat (7): $T_{O R . D}=(0.51 \times$ guanine-plus-cytosine content $)$ 


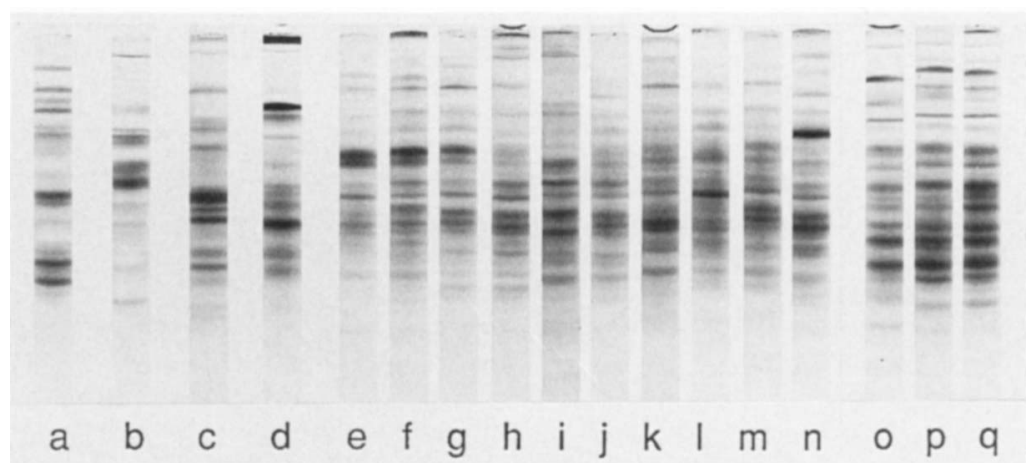

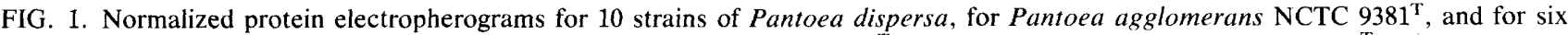
strains belonging to other, related taxa. Lane a, Erwinia ananas NCPPB $1846^{\mathrm{T}}$; lane b, Erwinia uredovora NCPPB $800^{\mathrm{T}}$; lane c, Erwinia stewartii NCPPB $2295^{\mathrm{T}}$; lane d, Pantoea agglomerans NCTC $9381^{\mathrm{T}}$; lanes e through $\mathrm{n}$, Pantoea dispersa NCPPB 2285, IPO 445, Gilardi 968, Gilardi 961, ATCC 14589 ${ }^{\mathrm{T}}$, NCPPB 2279, Graham G146, CDC 1429-71, Lille 214-6, and Goullet 29.2.80, respectively; lane o, Enterobacter agglomerans Gilardi 1030; lane p, Erwinia herbicola Angers B.6.2; lane q, Enterobacter agglomerans Gilardi 953.

+ 28.0. The mean guanine-plus-cytosine content of the labeled DNA of strain ATCC $14589^{\mathrm{T}}$ was $56.5 \pm 0.5 \mathrm{~mol} \%$ (three determinations), as determined by the thermal denaturation method $(6,25)$. Consequently, the optimal temperature of renaturation was $56.8^{\circ} \mathrm{C}$. The rate of reassociation was calculated by using the formula of De Ley and Tytgat (7).

The $\Delta T_{m}$ (the difference, in degrees Celsius, between the $T_{m}$ [the temperature at which $50 \%$ of the DNA was denatured] of the hybrid molecule and the $T_{m}$ of the homologous DNA) was determined for Erwinia herbicola NCPPB 2285 and IPO 445. This experiment was performed by using the technique described by De Ley et al. (8).

Polyacrylamide gel electrophoresis of soluble proteins. Protein electropherograms were prepared as described previously (26).

Characterization of strains by the API 20E system. Tests in API 20E strips (API System, Montalieu-Vercieu, France) were performed at $30^{\circ} \mathrm{C}$ by using procedures described previously (27). Results were coded and interpreted by using APILAB computer program V2.0.

\section{RESULTS}

DNA hybridizations. Radioactive DNA from Erwinia herbicola ATCC $14589^{\mathrm{T}}$ was hybridized to filter-bound DNAs of 34 strains belonging to the Erwinia herbicola-Enterobacter agglomerans complex, to the DNAs of the type strains of five other Erwinia species, to DNAs from 10 strains belonging to other Enterobacter species, and to DNAs from 38 strains representing 37 other species belonging to the family Enterobacteriaceae (Table 1).

Five strains belonging to phenotypic group B5 (11) and three strains belonging to phenotypic group 10 (32) exhibited 76 to $92 \%$ DNA binding to Erwinia herbicola ATCC $14589^{\mathrm{T}}$. A high level of relative DNA binding $(85 \%)$ was also observed with strain CDC 1429-71, which represents DNA hybridization group III of Brenner et al. (3). The differences in thermal elution midpoints $\left(\Delta T_{m}\right)$ between homologous and heterologous duplexes were 0.5 and $2.6^{\circ} \mathrm{C}$ for two of these strains (strains NCPPB 2285 and IPO 445, respectively). These 10 strains constitute a genomic group provisionally referred to as DNA hybridization group 14589.

The two remaining strains of phenotypic group B5 (strains Gilardi 953 and Angers B.6.2) (11) and strain Gilardi 1030, a member of phenotypic group 10 (32), exhibited only 41, 39, and $44 \%$ DNA binding, respectively, to reference strain ATCC $14589^{\mathrm{T}}$.

The levels of DNA binding between strain ATCC $14589^{\mathrm{T}}$ and six strains belonging to DNA hybridization group 27155 , as previously defined by Beji et al. (1), were between 41 and $53 \%$; the levels of DNA binding were less than $38 \%$ with strains belonging to other phenotypic groups (groups B1, B2, B6, B7, B9, and E1) of Gavini et al. (11). Representative strains belonging to DNA hybridization groups II, IV, V to $X$, and XII of Brenner et al. (3) exhibited 20 to $47 \%$ DNA binding to strain ATCC $14589^{\mathrm{T}}$.

DNA binding levels of 51,47 , and $39 \%$ were obtained with the type strains of Erwinia stewartii, Erwinia uredovora, and Erwinia ananas, respectively, and DNA binding levels of 28 and $19 \%$ were observed with the type strains of Erwinia carotovora and Erwinia amylovora (type species [29]), respectively. A DNA binding level of $35 \%$ was observed with the type strain of Enterobacter dissolvens (synonym, Erwinia dissolvens [4]); DNA binding levels of less than $25 \%$ were obtained with strains belonging to other Enterobacter species (including the type species, Enterobacter cloacae [29]), and DNA binding levels of less than $38 \%$ were observed with strains belonging to 37 other species of the family Enterobacteriaceae.

Comparison of protein electropherograms. Protein electropherograms were prepared from eight strains belonging to phenotypic group B5 (11), four additional strains belonging to phenotypic group 10 (32), reference strain CDC 1429-71 of DNA hybridization group III of Brenner et al. (3), and type strains Enterobacter agglomerans NCTC 9381 (= ATCC 27155), Erwinia ananas NCPPB 1846, Erwinia uredovora NCPPB 800, and Erwinia stewartii NCPPB 2295. Normalized photographs of the protein electropherograms are shown in Fig. 1.

It is apparent that the 10 strains belonging to DNA hybridization group 14589 , as delineated above, have many similarities in their protein patterns. The electropherograms of these strains differ significantly from the electrophero-

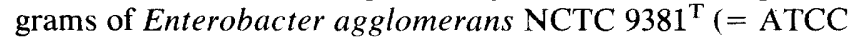
$27155^{\mathrm{T}}$ ), Erwinia ananas NCPPB $1846^{\mathrm{T}}$, Erwinia uredovora NCPPB $800^{\mathrm{T}}$, and Erwinia stewartii NCPPB $2295^{\mathrm{T}}$.

Strains Gilardi 953 and Angers B.6.2 (which were classified in group B5 [11]) and strain Gilardi 1030 (a member of phenotypic group 10, but classified outside group B5 by Gavini et al. [11, 29]) constitute a separate, homogeneous 
TABLE 2. Phenotypic characteristics of Pantoea agglomerans and Pantoea dispersa (DNA hybridization group 14589) ${ }^{a}$

\begin{tabular}{|c|c|c|c|c|c|c|c|c|}
\hline \multirow[b]{2}{*}{ Characteristic } & \multicolumn{3}{|c|}{ Pantoea agglomerans (16 strains) } & \multicolumn{3}{|c|}{ Pantoea dispersa (10 strains) } & \multirow{2}{*}{$\begin{array}{c}\text { Pantoea } \\
\text { agglomerans } \\
\text { ATCC } 27155^{\mathrm{T} b}\end{array}$} & \multirow{2}{*}{$\begin{array}{c}\text { Pantoea } \\
\text { dispersa } \\
\text { ATCC } 14589\end{array}$} \\
\hline & Reaction & $\begin{array}{c}\% \text { of } \\
\text { strains } \\
\text { positive }\end{array}$ & $\begin{array}{l}\% \text { of strains } \\
\text { having slow } \\
\text { reaction }\end{array}$ & Reaction & $\begin{array}{l}\% \text { of } \\
\text { strains } \\
\text { positive }\end{array}$ & $\begin{array}{l}\% \text { of strains } \\
\text { having slow } \\
\text { reaction }\end{array}$ & & \\
\hline Production of yellow pigment & + & 100 & & + or - & 60 & & + & + \\
\hline Growth at $4^{\circ} \mathrm{C}$ & $(+)$ or + & 12 & 81 & - & 0 & & $(+)(5)$ & - \\
\hline Growth at $41^{\circ} \mathrm{C}$ & - or $(+)$ & 0 & 12 & + & 90 & 10 & - & + \\
\hline Growth at $44^{\circ} \mathrm{C}$ & - & 0 & & - & 0 & 10 & - & - \\
\hline Motility & + & 100 & & + & 90 & 10 & + & + \\
\hline KCN (growth) & + or - & 75 & & + & 90 & & + & - \\
\hline Gelatin liquefaction & $(+)$ & & 100 & $(+)$ & 0 & 90 & $(+)(15)$ & $(+)(16)$ \\
\hline Indole production & - & 0 & & - & 0 & & - & - \\
\hline Voges-Proskauer reaction & + & 94 & & + & 100 & & + & + \\
\hline Nitrate reduced to nitrite & + & 94 & & + or - & 70 & & + & - \\
\hline $\mathrm{H}_{2} \mathrm{~S}$ production & - & 0 & & - & 0 & & - & - \\
\hline Hydrolysis of esculin & + & 100 & & - & 0 & & + & - \\
\hline Gas produced from D-glucose & - & 0 & & - & 0 & & - & - \\
\hline Arginine dihydrolase (Moeller) & - & 0 & & - & 0 & & - & - \\
\hline Lysine decarboxylase (Moeller) & - & 0 & & - & 0 & & - & - \\
\hline Ornithine decarboxylase (Moeller) & - or + & 31 & & - & 10 & & - & + \\
\hline Phenylalanine deaminase & + or - & 86 & & - & 0 & & - & - \\
\hline Tetrathionate reductase & - or + & 12 & & - & 0 & & - & - \\
\hline Deoxyribonuclease & - & 0 & & - & 0 & & - & - \\
\hline$\beta$-Xylosidase & - & 0 & & - & 0 & & - & - \\
\hline$\beta$-Galactosidase & + & 100 & & + & 100 & & + & + \\
\hline Urease & - & 0 & & - & 0 & & - & - \\
\hline \multicolumn{9}{|l|}{ Utilization of: } \\
\hline Citrate (Simmons) & + & 94 & & + & 100 & & + & + \\
\hline Malonate & + & 100 & & - & 10 & & + & + \\
\hline D-Tartrate (Kauffman) & - & 6 & & - or + & 30 & & + & - \\
\hline L-Tartrate (Kauffman) & - & 0 & & + or - & 50 & & - & - \\
\hline meso-Tartrate (Kauffman) & - & 0 & & + or - & 80 & & - & + \\
\hline Mucate (Kauffman) & - & 0 & & - or + & 40 & & - & - \\
\hline \multicolumn{9}{|l|}{ Acid produced from: } \\
\hline L-Arabinose & + & 100 & & $\mathrm{~d}$ & 60 & 10 & + & + \\
\hline D-Ribose & + & 100 & & + & 100 & & + & + \\
\hline D-Xylose & + & 100 & & + & 100 & & + & + \\
\hline D-Fructose & + & 100 & & + & 100 & & + & + \\
\hline D-Mannose & + & 100 & & + & 100 & & + & + \\
\hline L-Rhamnose & + & 95 & 5 & + & 100 & & + & + \\
\hline L-Sorbose & - & 0 & & - & 0 & & - & - \\
\hline D-Cellobiose & $\mathrm{d}$ & 44 & 44 & + or $(+)$ & 50 & 50 & $(+)(12)$ & $(+)(8)$ \\
\hline D-Galactose & + & 100 & & + & 100 & & + & + \\
\hline Lactose & $\mathrm{d}$ & 19 & 6 & - & 0 & 10 & - & - \\
\hline Maltose & + & 100 & & + & 100 & & + & + \\
\hline Melibiose & - & 0 & 6 & $\mathrm{~d}$ & 10 & 30 & - & + \\
\hline Sucrose & + & 100 & & + & 100 & & + & + \\
\hline Trehalose & + & 100 & & + & 100 & & + & + \\
\hline Melezitose & - & 0 & & - & 0 & & - & - \\
\hline Raffinose & $\mathrm{d}$ & 6 & 19 & - & 0 & & - & - \\
\hline Glycerol & $(+)$ & & 100 & $(+)$ or + & 20 & 70 & $(+)(4)$ & + \\
\hline meso-Erythritol & - & 0 & & - & 0 & 10 & - & - \\
\hline Adonitol & - & 0 & 6 & - & 0 & & $(+)(12)$ & - \\
\hline Dulcitol & - & 0 & & - & 0 & 10 & - & - \\
\hline Inositol & - or $(+)$ & 0 & 37 & $\mathrm{~d}$ & 60 & 20 & $(+)(15)$ & + \\
\hline D-Mannitol & + & 100 & & + & 100 & & + & + \\
\hline$D$-Sorbitol & - & 0 & & - & 0 & & - & - \\
\hline$\alpha$-Methyl-D-glucoside & - & 0 & & - & 0 & & - & - \\
\hline Salicin & + & 100 & & - or $(+)$ & 0 & 50 & + & - \\
\hline Glycogen & - & 0 & & - or + & 40 & & - & - \\
\hline Inulin & - or + & 12 & & - & 0 & & - & - \\
\hline Tartrate (Jordan) & - & 0 & & - or + & 40 & & - & - \\
\hline
\end{tabular}

${ }^{a}+$, Reaction present in at least $90 \%$ of the strains within 24 to $48 \mathrm{~h} ;-$, reaction absent in at least $90 \%$ of the strains after 2 days; $(+)$, slow reaction (between 2 and 30 days; the numbers in parentheses indicate the numbers of days necessary for the reaction to occur); d, different reactions. When more than one symbol is used (e.g., (+ or -), the first symbol indicates the most frequent result. Tests were done at $30^{\circ} \mathrm{C}$, unless indicated otherwise.

${ }^{b}$ Data from reference 1 . 
TABLE 3. Differential characteristics of Pantoea agglomerans, Pantoea dispersa, and the species previously assigned or phenotypically related to the Erwinia herbicola-Enterobacter agglomerans complex ${ }^{a}$

\begin{tabular}{|c|c|c|c|c|c|c|c|c|c|c|c|}
\hline Characteristic & $\begin{array}{l}\text { Pantoea } \\
\text { agglo- } \\
\text { merans }\end{array}$ & $\begin{array}{l}\text { Pantoea } \\
\text { dispersa }\end{array}$ & $\begin{array}{c}\text { Erwinia } \\
\text { uredovora }\end{array}$ & $\begin{array}{l}\text { Erwinia } \\
\text { ananas }\end{array}$ & $\begin{array}{l}\text { Erwinia } \\
\text { stewartii }\end{array}$ & $\begin{array}{l}\text { Leclercia } \\
\text { adecar- } \\
\text { boxylata }\end{array}$ & $\begin{array}{l}\text { Escherichia } \\
\text { hermannii }\end{array}$ & $\begin{array}{l}\text { Escherichia } \\
\text { vulneris }\end{array}$ & $\begin{array}{c}\text { Enterobacter } \\
\text { sakazakii }\end{array}$ & $\begin{array}{l}\text { Rahnella } \\
\text { aquatilis }\end{array}$ & $\begin{array}{l}\text { Ewingella } \\
\text { americana }\end{array}$ \\
\hline $\begin{array}{l}\text { Production of yellow } \\
\text { pigment }\end{array}$ & + & d & + & + & + & + & + & d & + & - & - \\
\hline Indole production & - & - & + & + & - & + & + & - & $(-)$ & - & - \\
\hline Voges-Proskauer reaction & + & + & + & + & - & - & - & - & + & + & + \\
\hline Arginine dihydrolase & - & - & - & - & - & - & - & d & + & - & - \\
\hline Lysine decarboxylase & - & - & - & - & - & - & - & $(+)$ & - & - & - \\
\hline Ornithine decarboxylase & d & - & - & - & - & - & + & - & + & - & - \\
\hline \multicolumn{12}{|l|}{ Acid produced from: } \\
\hline D-Cellobiose & d & $\mathrm{d}$ & + & + & + & + & + & + & + & + & + \\
\hline Lactose & d & - & + & + & + & + & $\mathrm{d}$ & $(-)$ & + & + & d \\
\hline Maltose & + & + & + & + & - & + & + & + & + & + & + \\
\hline Melibiose & - & $\mathrm{d}$ & + & + & + & + & - & + & + & + & NT \\
\hline Raffinose & $\mathrm{d}$ & - & + & + & + & + & $\mathrm{d}$ & + & + & + & - \\
\hline Sucrose & + & + & + & + & + & + & d & - & + & + & - \\
\hline Adonitol & - & - & + & - & - & + & - & - & - & - & - \\
\hline Dulcitol & - & - & - & - & - & + & $(-)$ & - & - & $(+)$ & - \\
\hline Sorbitol & - & - & + & + & + & - & - & - & - & + & - \\
\hline$\alpha$-Methyl-D-glucoside & - & - & - & _- & - & - & - & d & + & - & - \\
\hline Salicin & + & - & $\mathrm{d}$ & + & - & + & d & d & + & + & + \\
\hline
\end{tabular}

$a+$, Reaction present in at least $90 \%$ of the strains; - , reaction absent in at least $90 \%$ of the strains; $(+)$, reaction present in 76 to $89 \%$ of the strains; $(-)$, reaction present in 11 to $25 \%$ of the strains; d, reaction present in 26 to $75 \%$ of the strains; NT, not tested. Data were obtained after $48 \mathrm{~h}$ of incubation at $30^{\circ} \mathrm{C}$ (Pantoea and Erwinia species) or $36 \pm 1^{\circ} \mathrm{C}$ (other species). See references 2, 21, and 22.

electrophoretic group, with protein patterns that are very different from those of all other strains examined.

API $20 E$ seven-digit codes. The strains of DNA hybridization group 14589 , as delineated above, were tested by using the API 20E system. Five strains gave the numerical code 1205173; strains NCPPB 2285 and Goullet 29.2.80 differed because of negative reactions in the API $20 \mathrm{E}$ amygdalin test and gave the code 1205172. Both of these codes were identified by the APILAB program as Enterobacter agglomerans or Erwinia sp. Strains Lille 214-6 and ATCC $14589^{\mathrm{T}}$ did not produce acid from L-rhamnose in API 20E strips and gave the code 1205163. Strain CDC 1429-71 produced acid from inositol and sorbitol but did not utilize citrate in the API 20E strips; consequently, code 1005773 was obtained. The latter two codes could not be identified unambiguously by the APILAB program, even when additional tests were taken into account; Enterobacter agglomerans was listed as one of the possibilities.

For comparison, strains Gilardi 953, Gilardi 1030, and Angers B.6.2, which were phenotypically similar to the strains belonging to DNA hybridization group $14589(11,32)$ but were genomically and electrophoretically different (Table 1 and Fig. 1), were also examined by using the API 20E system. Strains Gilardi 953 and Angers B.6.2 yielded codes different from those mentioned above. Strain Gilardi 1030 gave the code 1205172 , which was also found for two strains belonging to DNA hybridization group 14589 (see above).

\section{DISCUSSION}

The following 10 strains exhibited more than $75 \%$ DNA binding to Erwinia herbicola ATCC $14589^{\mathrm{T}}: 6$ strains belonging to phenotypic group B5 of Gavini et al. (11) (strains ATCC $14589^{\mathrm{T}}$, Lille 214-6, Gilardi 961, Gilardi 968, Graham G146, and Goullet 29.2.80), 3 strains belonging to phenotypic group 10 of Verdonck et al. (32) (strains NCPPB 2279, NCPPB 2285, and IPO 445), and strain CDC 1429-71 (Table 1). The $\Delta T_{m}$, determined for strains NCPPB 2285 and IPO
445 , was less than $2.7^{\circ} \mathrm{C}$. We provisionally referred to this group as DNA hybridization group 14589 , which includes strains belonging to DNA hybridization group III of Brenner et al. (3) (strains ATCC $14589^{\mathrm{T}}$ and CDC 1429-71). In the opinion of Brenner et al. (3), each of their DNA hybridization groups constitutes a unique species. The high level of genomic relatedness of the strains belonging to DNA hybridization group 14589 was confirmed by the similarities observed in their electrophoretic protein patterns (Fig. 1).

Levels of DNA binding less than $54 \%$ were observed between strain ATCC $14589^{\mathbf{T}}$ and all of the other strains tested, including three strains (strains Gilardi 953, Gilardi 1030, and Angers B.6.2) which have been classified in the same phenotypic groups as the strains belonging to DNA hybridization group 14589 (Table 1) (11, 32). These strains constituted a separate electrophoretic group (Fig. 1).

On the basis of the present data it is clear that DNA hybridization group 14589 constitutes a discrete species within the family Enterobacteriaceae. The closest relative of this species is DNA hybridization group 27155, as defined by Beji et al. (1), with which it exhibits up to $53 \%$ DNA relatedness. The latter group consists of strains received as Enterobacter agglomerans, Erwinia herbicola, and Erwinia milletiae, including the type strains of these three species, and reference strains belonging to DNA hybridization groups $\mathrm{V}$ and XIII of Brenner et al. $(1,3)$. The degrees of genomic relatedness (levels of DNA binding) observed by Brenner et al. (3) between their DNA hybridization group III (which corresponds to our group 14589) and their DNA hybridization groups $\mathrm{V}$ and XIII (corresponding together to group 27155 [1]) were 50 to $56 \%$, which is in good agreement with our results (Table 1). Beji et al. suggested (1) that DNA hybridization group 27155 might constitute a single species within a new enterobacterial genus, but this suggestion was not implemented by nomenclatural proposals. As discussed by Beji et al. (1), a problem arose with the delineation of DNA hybridization group 27155 as a single species. Reference strain CDC 3482-71 belonging to DNA hybridization 
group $\mathrm{V}$ of Brenner et al. (3) exhibited only $62 \%$ DNA binding to Enterobacter agglomerans ATCC $27155^{\mathrm{T}}$, which is in good agreement with the percentages found by Brenner et al. (3) and Lind and Ursing (23) with other, genomically comparable reference strains. Lind and Ursing also reported a $\Delta T_{m}$ of $13.8^{\circ} \mathrm{C}$ (in their experiments at $60^{\circ} \mathrm{C}$ ) and only $38 \%$ DNA binding when the incubation temperature was in creased to $75^{\circ} \mathrm{C}$. Thus, DNA hybridization group 27155 (1) does not meet the definition of a species as recommended by Wayne et al. (33). Therefore, we have to exclude strain CDC 3482-71. As the latter strain is a representative of protein profile group II of Beji et al. (1), the three other strains of this protein profile group also have to be excluded. It has been shown that strains with similar protein electropherograms are genomically highly related and should not be classified in different species (15-17; this paper). As the three other strains of protein profile group II exhibited up to $77 \%$ DNA binding to Enterobacter agglomerans ATCC $27155^{\mathrm{T}}$ (1), we also provisionally delete the four strains of protein profile group VII of Beji et al. (1), because strains of the latter protein profile group exhibited less than $77 \%$ DNA binding to Enterobacter agglomerans ATCC $27155^{\mathrm{T}}$ (1).

DNA hybridization group 14589 (Table 1) and DNA hybridization group 27155 (with protein profile groups II and VII [1] and DNA hybridization group V of Brenner et al. [3] excluded) should be united as separate species in a single, new genus, because they form a distinct genomic $(1,3,23)$ (Table 1$)$ and phenotypic $(11,27,32)$ entity within the family Enterobacteriaceae.

We propose the name Pantoea gen. nov., for the new taxon, with the two species described below. The name Pantoea dispersa sp. nov. is proposed for the 10 strains belonging to DNA hybridization group 14589 (Table 1); from the data of Brenner et al. (3) it follows that the strains belonging to their DNA hybridization group III should also be included in this species, as both groups have strains in common. The name Pantoea agglomerans comb. nov. is proposed for the 52 strains belonging to protein electrophoretic profile groups I and III to VI as defined by Beji et al. (1); this species includes the strains belonging to DNA hybridization group XIII of Brenner et al. (3) and the 52 strains genomically identified as Enterobacter agglomerans by Lind and Ursing (23). Pantoea agglomerans includes the type strains of Enterobacter agglomerans (Beijerinck 1888) EWing and Fife 1972, Erwinia herbicola (Löhnis 1911) Dye 1964, and Erwinia milletiae (Kawakami and Yoshida 1920) Magrou 1937 (29). According to the International Code of Nomenclature of Bacteria (19), the species epithet agglomerans has priority over the epithets herbicola and milletiae and was consequently selected for the new combination Pantoea agglomerans. The strains belonging to protein electrophoretic profile groups II and VII of Beji et al. (1) and DNA hybridization group $\mathrm{V}$ of Brenner et al. (3) are provisionally classified as Pantoea sp., until their interrelatedness is elucidated.

The data presented here and previously $(1,3,23)$ suggest that other groups within the so-called Erwinia herbicolaEnterobacter agglomerans complex might also be included as additional species in the genus Pantoea. Strains representing some other DNA hybridization groups of Brenner et al. (3) and the type strains of Erwinia stewartii and Erwinia uredovora exhibited about $50 \%$ DNA binding to the two Pantoea species (Table 1) (1). Slightly less DNA binding (39 to $49 \%$ ) was observed with strains Gilardi 1030 , Gilardi 953 , and Angers B.6.2 (Table 1) (1), which constituted a separate protein electrophoretic group (Fig. 1) but were found to be phenotypically close to Pantoea dispersa strains $(11,32)$. Erwinia ananas NCPPB $1846^{\mathrm{T}}$ was found to be $56 \%$ related to Pantoea agglomerans ATCC $27155^{\mathrm{T}}$ (1), but only $39 \%$ related to Pantoea dispersa ATCC $14589^{\mathrm{T}}$ (Table 1). More data on more strains are needed to confirm these observations and to clarify the taxonomic position of these groups and species.

Finally, data presented here or published previously (1, 27) strongly suggest that extreme caution should be used in identification of strains as Enterobacter agglomerans, Erwinia herbicola, or Pantoea sp. when researchers rely solely on rapid, commercialized identification systems. With one such system, API 20E test strips, we were unable to differentiate unequivocally among some strains of Pantoea dispersa and Pantoea agglomerans, other named Enterobacter agglomerans and Erwinia herbicola strains, and strains of other Erwinia species or of other genera $(1,27$; this paper). Some helpful additional discriminating features, which are not contained in some of the rapid systems, are shown in Tables 2 and 3.

Description of Pantoea gen. nov. Pantoea (Pan. toe'a. Gr. adj. pantoios, of all sorts and sources; M. L. fem. n. Pantoea, [bacteria] from diverse [geographical and ecological] sources). Gram-negative, noncapsulated, nonsporeforming straight rods measuring 0.5 to 1.0 by 1.0 to $3.0 \mu \mathrm{m}$. Most are motile and are peritrichously flagellated. Colonies on nutrient agar are smooth, translucent, and more or less convex with entire margins. Colonies may or may not be yellow pigmented. Facultatively anaerobic; oxidase negative. Acid is produced from D-xylose, D-ribose, maltose, D-galactose, D-mannose, D-fructose, trehalose, and D-mannitol. Isolated from plant surfaces, seeds, soil, and water, as well as from humans (wounds, blood, urine, internal organs) and animals, in several parts of the world.

The guanine-plus-cytosine content of the DNA is 55.1 to $60.6 \mathrm{~mol} \%(1,5,9,30$; Mergaert, unpublished data), as determined by the $T_{m}$ method.

The type species is Pantoea agglomerans (Beijerinck 1888) comb. nov.

Description of Pantoea agglomerans. Pantoea agglomerans (Beijerinck 1888) comb. nov. (Enterobacter agglomerans (Beijerinck 1888) Ewing and Fife 1972) (ag. glo' mer. ans. L.v. agglomerare, to form into a ball; L. part. adj. agglomerans, forming into a ball).

The species has all of the characteristics of the genus. The specific description below is mainly based on 16 strains studied by conventional methods by Gavini et al. (11).

Culture conditions. Strains grow well on nutrient agar at $30^{\circ} \mathrm{C}$ but not at $44^{\circ} \mathrm{C}$.

Biochemical characteristics. The biochemical characteristics at $30^{\circ} \mathrm{C}(11)$ are shown in Tables 2 and 3 .

Nutritional characteristics. The following carbon sources are utilized at $30^{\circ} \mathrm{C}$ by 90 to $100 \%$ of the strains within 5 days: glycerol, meso-inositol, D-mannitol, L-arabinose, Dribose, D-xylose, D-galactose, D-glucose, D-fructose, D-mannose, L-rhamnose, D-maltose, sucrose, trehalose, salicin, $\mathrm{N}$-acetyl-D-glucosamine, D-gluconate, 2-keto-D-gluconate, succinate, fumarate, DL-glycerate, D-malate, L-malate, meso-tartrate, cis-aconitate, L-glutamate, L-proline, DL-4aminobutyrate, and glucosamine.

The following carbon sources are not utilized at $30^{\circ} \mathrm{C}$ by 90 to $100 \%$ of the strains within 5 days: adonitol, dulcitol, sorbitol, meso-xylitol, L-arabitol, meso-erythritol, L-xylose, L-sorbose, melibiose, gentiobiose, D-melizitose, D-tagatose, $D$-fucose, L-fucose, D-turanose, $\alpha$-methyl-D-mannoside, $\alpha$ methyl-D-glucoside, $\beta$-methyl-D-xyloside, amygdalin, arbu- 
tin, esculin, inulin, starch, glycogen, acetate, propionate, butyrate, isobutyrate, $n$-valerate, isovalerate, $n$-caproate, heptanoate, caprylate, pelargonate, caprate, oxalate, maleate, glutarate, adipate, pimelate, suberate, azelate, sebacate, glycolate, DL-3-hydroxybutyrate, levulinate, citraconate, itaconate, mesaconate, phenylacetate, benzoate, $o$-hydroxybenzoate, $m$-hydroxybenzoate, $p$-hydroxybenzoate, Dmandelate, L-mandelate, phthalate, isophthalate, terephthalate, glycine, L-leucine, L-norleucine, DL-2-aminobutyrate, L-threonine, L-methionine, L-phenylalanine, L-tyrosine, Dtryptophan, L-tryptophan, trigonelline, L-ornithine, L-lysine, $\mathrm{L}$-citrulline, L-arginine, DL-kynurenine, betaine, creatin, $\beta$ alanine, DL-3-aminobutyrate, DL-5-aminovalerate, DL-2-aminobenzoate, DL-3-aminobenzoate, DL-4-aminobenzoate, urea, acetamide, sarcosine, ethylamine, butylamine, amylamine, ethanolamine, benzylamine, putrescine, spermine, histamine, and tryptamine.

DNA base composition. The guanine-plus-cytosine contents of 21 strains range from 55.1 to $56.8 \mathrm{~mol} \%(5,27$; Mergaert, unpublished data), as determined by the $T_{m}$ method.

Habitat. Isolated from plant surfaces, seeds, and water, as well as from humans (wounds, blood, urine, internal organs) and animals. Some strains (synonym, Erwinia milletiae) have been reported to cause galls on Wisteria floribunda and Wisteria japonica, some strains have been reported to cause galls on Gypsophila paniculata, and some strains have been reported to cause stalk and leaf necrosis on onions (14).

The strain is strain ATCC 27155 (= CDC 1461-67 = NCTC $9381=\mathrm{LMG} 1286=\mathrm{ICPB} 3435$ ), which was isolated from a knee laceration in Zimbabwe.

Description of Pantoea dispersa sp. nov. Pantoea dispersa (dis. per' sa. L. v. dispergere, to spread, to scatter; L. fem. part. adj. dispersa, spread, scattered). The species has all of the characteristics of the genus, as well as the characteristics described below.

Culture conditions. Strains grow at neither 4 nor $44^{\circ} \mathrm{C}$, but grow well on nutrient agar at 30 and $41^{\circ} \mathrm{C}$.

Biochemical characteristics. The biochemical characteristics at $30^{\circ} \mathrm{C}(11)$ are shown in Tables 2 and 3.

Nutritional characteristics. The following carbon sources are utilized at $30^{\circ} \mathrm{C}$ by 90 to $100 \%$ of the strains within 5 days: glycerol, meso-erythritol, meso-inositol, D-arabitol, D-mannitol, L-arabinose, D-ribose, D-xylose, D-galactose, D-glucose, D-fructose, D-mannose, L-rhamnose, amygdalin, D-cellobiose, D-maltose, sucrose, trehalose, gentiobiose, D-lyxose, D-gluconate, 2-keto-D-gluconate, 5-keto-D-gluconate, succinate, fumarate, DL-lactate, DL-glycerate, Lmalate, L-tartrate, meso-tartrate, cis-aconitate, citrate, Lhistidine, L-aspartate, L-glutamate, DL-4-aminobutyrate, and glucosamine.

The following carbon sources are not utilized at $30^{\circ} \mathrm{C}$ by 90 to $100 \%$ of the strains within 5 days: adonitol, dulcitol, sorbitol, meso-xylitol, L-arabitol, L-xylose, L-sorbose, lactose, melibiose, D-melizitose, D-raffinose, D-tagatose, Dfucose, L-fucose, D-turanose, $\beta$-methyl-D-xyloside, $\alpha$ methyl-D-mannoside, $\alpha$-methyl-D-glucoside, inulin, starch, glycogen, propionate, butyrate, isobutyrate, $n$-valerate, isovalerate, $n$-caproate, heptanoate, caprylate, pelargonate, caprate, oxalate, malonate, maleate, glutarate, adipate, pimelate, suberate, azelate, sebacate, glycolate, DL-3-hydroxybutyrate, D-tartrate, levulinate, citraconate, itaconate, mesaconate, phenylacetate, benzoate, $o$-hydroxybenzoate, $m$-hydroxybenzoate, $p$-hydroxybenzoate, D-mandelate, Lmandelate, phthal te, isophthalate, terephthalate, glycine, L-leucine, L-isoleucine, L-norleucine, L-valine, DL-norval- ine, DL-2-aminobutyrate, L-threonine, L-methionine, Lphenylalanine, L-tyrosine, D-tryptophan, L-tryptophan, trigonelline, L-lysine, L-citrulline, L-arginine, DL-kynurenine, betaine, creatin, $\beta$-alanine, DL-3-aminobutyrate, DL-5-aminovalerate, DL-2-aminobenzoate, DL-3-aminobenzoate, DL4-aminobenzoate, urea, acetamide, sarcosine, butylamine, benzylamine, putrescine, spermine, histamine, and tryptamine.

DNA base composition. The guanine-plus-cytosine contents of four strains are 56.5 mol\% (strain ATCC $14589^{\mathrm{T}}$ ) (this paper), 58.6 mol\% (strain Graham G146) (5), $59.1 \mathrm{~mol} \%$ (strain NCPPB 2285) (Mergaert, unpublished data), and 60.6 mol\% (strain IPO 445) (9), as determined by the $T_{m}$ method.

Habitat. Isolated from plant surfaces, seeds, humans, and the environment.

Type strain. The type strain is strain ATCC 14589 (= LMG 2603), which was isolated from soil in Japan (18).

The biochemical characteristics of type strains Pantoea agglomerans ATCC 27155 and Pantoea dispersa ATCC 14589 are shown in Table 2.

Differential characteristics for Pantoea agglomerans, Pantoea dispersa, and the species previously classified in or phenotypically related to the Erwinia herbicolaEnterobacter agglumerans complex are shown in Table 3. Additional differential characteristics that differentiate Pantoea agglomerans and Pantoea dispersa are utilization of meso-erythritol, amygdalin, and gentiobiose as carbon sources within 5 days at $30^{\circ} \mathrm{C}$ (absent in the former species and present in the latter species).

\section{ACKNOWLEDGMENTS}

J.D.L. is indebted to the Instituut tot Aanmoediging van het Wetenschappelijk Onderzoek in Nijverheid en Landbouw, Belgium, and to the Nationaal Fonds voor Geneeskundig Onderzoek, Belgium, for several grants. K.K. is indebted to the Nationaal Fonds voor Wetenschappelijk Onderzoek, Belgium, for equipment grants, and J.M. is indebted to the Institut tot Aanmoediging van het Wetenschappelijk Onderzoek in Nijverheid en Landbouw, Belgium, for a scholarship.

\section{LITERATURE CITED}

1. Beji, A. J. Mergaert, F. Gavini, D. Izard, K. Kersters, H. Leclerc, and J. De Ley. 1988. Subjective synonymy of Erwinia herbicola, Erwinia milletiae, and Enterobacter agglomerans and redefinition of the taxon by genotypic and phenotypic data. Int. J. Syst. Bacteriol. 38:77-88.

2. Brenner, D. J. 1984. Family I. Enterobacteriaceae Rahn 1937, p. 408-420. In N. R. Krieg and J. G. Holt (ed.), Bergey's manual of systematic bacteriology, vol. 1. The Williams \& Wilkins Co., Baltimore.

3. Brenner, D. J., G. R. Fanning, J. K. Leete Knutson, A. G. Steigerwalt, and M. I. Krichevsky. 1984. Attempts to classify herbicola group-Enterobacter agglomerans strains by deoxyribonucleic acid hybridization and phenotypic tests. Int. J. Syst. Bacteriol. 34:45-55.

4. Brenner, D. J., A. C. McWhorter, A. Kai, A. G. Steigerwalt, and J. J. Farmer III. 1986. Enterobacter asburiae sp. nov., a new species found in clinical specimens, and reassignment of $\mathrm{Er}$ winia dissolvens and Erwinia nimipressuralis to the genus Enterobacter as Enterobacter dissolvens comb. nov. and Enterobacter nimipressuralis comb. nov. J. Clin. Microbiol. 23: $1114-1120$

5. De Ley, J. 1968. DNA base composition of yellow Erwinia strains. Antonie van Leeuwenhoek J. Microbiol. Serol. 34: 257-262.

6. De Ley, J. 1970. Reexamination of the association between melting point, buoyant density and chemical base composition of deoxyribonucleic acid. J. Bacteriol. 101:738-754.

7. De Ley, J., and R. Tytgat. 1970. Evaluation of membrane filter 
methods for DNA-DNA hybridization. Antonie van Leeuwenhoek J. Microbiol. Serol. 36:461-474.

8. De Ley, J., R. Tytgat, J. De Smedt, and M. Michiels. 1973. Thermal stability of DNA:DNA hybrids within the genus Agrobacterium. J. Gen. Microbiol. 78:241-252.

9. De Smedt, J., and J. De Ley. 1977. Intra- and intergeneric similarities of Agrobacterium ribosomal ribonucleic acid cistrons. Int. J. Syst. Bacteriol. 27:222-240.

10. Ferragut, C., and H. Leclerc. 1976. Etude comparative des méthodes de détermination du $T_{m}$ de l'ADN bactérien. Ann. Microbiol. (Paris) 127A:223-235.

11. Gavini, F., B. Lefebvre, and H. Leclerc. 1983. Etude taxonomique de souches appartenant ou apparentées au genre Erwinia groupe Herbicola et à l'espèce Enterobacter agglomerans. Syst. Appl. Microbiol. 4:218-235.

12. Gilardi, G. L., and E. W. Bottone. 1971. Erwinia and yellow pigmented Enterobacter isolates from human sources. Antonie van Leeuwenhoek J. Microbiol. Serol. 37:529-535.

13. Graham, D. C., and W. Hodgkiss. 1967. Identity of Gramnegative, yellow pigmented, fermentative bacteria isolated from plants and animals. J. Appl. Bacteriol. 30:175-189.

14. Hattingh, M. J., and D. F. Walters. 1981. Stalk and leaf necrosis of onion caused by Erwinia herbicola. Plant Dis. 65:615-618.

15. Izard, D., J. Mergaert, F. Gavini, A. Beji, K. Kersters, J. De Ley, and H. Leclerc. 1985. Separation of Escherichia adecarboxylata from the "Erwinia herbicola-Enterobacter agglomerans" complex and from the other Enterobacteriaceae by nucleic acid and protein electrophoretic techniques. Ann. Inst. Pasteur (Paris) 136B:151-168.

16. Kersters, K. 1985 . Numerical methods in the classification of bacteria by protein electrophoresis, p. 337-368. In M. Goodfellow, D. Jones, and F. G. Priest (ed.), Computer-assisted bacterial systematics. Academic Press, Inc. (London), Ltd., London.

17. Kersters, K., and J. De Ley. 1975. Identification and grouping of bacteria by numerical analysis of their electrophoretic protein patterns. J. Gen. Microbiol. 87:333-342.

18. Komagata, K., Y. Tamagawa, and H. Iizuka. 1968. Characteristics of Erwinia herbicola. J. Gen. Appl. Microbiol. 14:19-37.

19. Lapage, S. P., P. H. A. Sneath, E. F. Lessel, V. B. D. Skerman, H. P. R. Seeliger, and W. A. Clark (ed.). 1975. International code of nomenclature of bacteria. 1975 Revision. American Society for Microbiology, Washington, D.C.

20. Leclerc, H. 1962. Etude biochimique d'Enterobacteriaceae pigmentées. Ann. Inst. Pasteur (Paris) 102:726-741.

21. Lelliott, R. A. 1974. Genus XII. Erwinia Winslow, Broadhurst, Buchanan, Krumwiede, Rogers and Smith 1920, p. 332-340. In
R. E. Buchanan and N. E. Gibbons (ed.), Bergey's manual of determinative bacteriology, 8th ed. The Williams \& Wilkins Co., Baltimore.

22. Lelliott, R. A., and R. S. Dickey. 1984. Genus VII. Erwinia Winslow, Broadhurst, Buchanan, Krumwiede, Rogers and Smith 1920, p. 469-476. In N. R. Krieg and J. G. Holt (ed.), Bergey's manual of systematic bacteriology, vol. 1. The Williams \& Wilkins Co., Baltimore.

23. Lind, E., and J. Ursing. 1986. Clinical strains of Enterobacter agglomerans (synonyms: Erwinia herbicola, Erwinia milletiae) identified by DNA-DNA hybridization. Acta Pathol. Microbiol. Immunol. Scand. Sect. B 94:205-213.

24. Marmur, J. 1961. A procedure for the isolation of deoxyribonucleic acid from microorganisms. J. Mol. Biol. 3:208-218.

25. Marmur, J., and P. Doty. 1962. Determination of the base composition of deoxyribonucleic acid from its thermal denaturation temperature. J. Mol. Biol. 5:109-118.

26. Mergaert, J., F. Gavini, K. Kersters, H. Leclerc, and J. De Ley. 1983. Phenotypic and protein electrophoretic similarities between strains of Enterobacter agglomerans, Erwinia herbicola, and Erwinia milletiae from clinical or plant origin. Curr. Microbiol. 8:327-331.

27. Mergaert, J., L. Verdonck, K. Kersters, J. Swings, J. M. Boeufgras, and J. De Ley. 1984. Numerical taxonomy of Erwinia species using API systems. J. Gen. Microbiol. 130:1893-1910.

28. Richard, C. 1974. Une nouvelle espèce d'entérobactérie rencontrée en bactériologie médicale Enterobacter agglomerans (exErwinia herbicola). Ann. Biol. Clin. 32:341-346.

29. Skerman, V. B. D., V. McGowan, and P. H. A. Sneath (ed.). 1980. Approved lists of bacterial names. Int. J. Syst. Bacteriol. 30:225-420.

30. Starr, M. P., and M. Mandel. 1969. DNA base composition and taxonomy of phytopathogenic and other enterobacteria. J. Gen. Microbiol. 56:113-123.

31. Tamura, K., R. Sakazaki, Y. Kosako, and E. Yoshizaki. 1986. Leclercia adecarboxylata gen. nov., comb. nov., formerly known as Escherichia adecarboxylata. Curr. Microbiol. 13: 179-184.

32. Verdonck, L., J. Mergaert, C. Rijckaert, J. Swings, K. Kersters, and J. De Ley. 1987. The genus Erwinia: a numerical analysis of phenotypic features. Int. J. Syst. Bacteriol. 37:4-18.

33. Wayne, L. G., D. J. Brenner, R. R. Colwell, P. A. D. Grimont, O. Kandler, M. I. Krichevsky, L. H. Moore, W. E. C. Moore, R. G. E. Murray, E. Stackebrandt, M. P. Starr, and H. G. Trüper. 1987. Report on the Ad Hoc Committee on Reconciliation of Approaches to Bacterial Systematics. Int. J. Syst. Bacteriol. 37:463-464. 